\title{
BIOLOGICAL ASPECTS OF THE SPINICAUDATA (BRANCHIOPODA, DIPLOSTRACA) IN THE LARGEST ALLUVIAL WETLAND IN CROATIA
}

\author{
BY
}

MARTA POPOVIĆ and SANJA GOTTSTEIN-MATOČEC ${ }^{1}$ )

Department of Zoology, Faculty of Science, Rooseveltov trg 6, HR-10000 Zagreb, Croatia

\begin{abstract}
Lonjsko Polje (Croatia) is among the largest alluvial wetlands in Europe. Temporary ponds that are the natural habitat for spinicaudatan branchiopods are very abundant in the area. We determined the time of occurrence, length of the life span, and the sexual structure and habitat characteristics of populations of Spinicaudata. Research took place from May to December 2004 at five sites. Three spinicaudatans were found: Cyzicus tetracerus (Krynicki, 1830) in spring (May to July) and autumn (late October), Eoleptestheria ticinensis (Balsamo-Crivelli, 1859) in spring (mid-May) and Leptestheria dahalacensis (Rüppell, 1837) in summer (mid-July). The length of their life span was 2-4 weeks. The populations of Cyzicus tetracerus, Eoleptestheria ticinensis, and Leptestheria dahalacensis consisted of males and females in an approximately $1: 1$ sex ratio. Ecological aspects of the habitat, including physico-chemical characteristics of the water as well as the structure and abundance of the associated fauna, were also observed.
\end{abstract}

\section{RÉSUMÉ}

Lonsko Polje (Croatie) compte parmi les zones humides alluviales les plus vastes d'Europe. Les mares temporaires, qui sont l'habitat naturel des branchiopodes Spinicaudata, sont très nombreuses dans cette région. Nous avons déterminé la période de présence, la longévité, la structure sexuelle et les caractéristiques de l'habitat des populations de Spinicaudata. Cette recherche a été réalisée de mai à décembre 2004 sur cinq sites. Trois Spinicaudata ont été trouvés : Cyzicus tetracerus (Krynicki, 1830) au printemps (mai à juillet) et en automne (fin octobre), Eoleptestheria ticinensis (Balsamo-Crivelli, 1859) au printemps (mi-mai), et Leptestheria dahalacensis (Rüppell, 1837) en été (mi-juillet). Leur temps de vie était de 2 à 4 semaines. Les populations de Cyzicus tetracerus, Eoleptestheria ticinensis et Leptestheria dahalacensis étaient composées de mâles et de femelles dans le sex-ratio d'approximativement $1: 1$. Les aspects écologiques de l'habitat, incluant les caractéristiques physico-chimiques de l'eau ainsi que la structure et l'abondance de la faune associée, ont été également observés.

1) Author for correspondence; e-mail: sgottst@zg.biol.pmf.hr 


\section{INTRODUCTION}

Lonjsko Polje (Croatia) is one of the largest alluvial wetlands in Europe, and on the Ramsar list of wetlands of international importance (Ramsar, 2005). Temporary ponds, the natural habitats of Spinicaudata, are abundant in that periodically inundated area. In this study, the term "temporary pond" was defined as: a body of standing water, between $25 \mathrm{~m}^{2}$ and 2 ha in surface area, which usually holds water from 1 to 4 months a year, and thus remains dry for most of the year (Nicolet et al., 2004). The spinicaudatans of Croatia have largely been neglected in the past, and data are generally scattered (Daday de Dées, 1923; Marinček \& Valvajter, 1979; Marinček \& Petrov, 1985, 1991, 1992b). Until now, there have been no records of spinicaudatans from Lonjsko Polje.

The community structure of spinicaudatan populations is the main indicator of the mode of reproduction, which in this group of clam shrimps varies widely, depending on the species. If males exceed or equal females in abundance, the obligatory sexual mode of reproduction is present in the population. This mode has been reported for nearly all species of the Cyzicidae and the Leptestheridae (cf. Sassaman, 1995). When males are present, but rare, a mixed mating system of sexual and parthenogenetic reproduction is suggested, which has been observed in some species of the Limnadiidae. A total absence of males indicates an obligatory parthenogenetic mode of reproduction, as reported for Cyzicus gynecia (Mattox, 1950) (Cyzicidae), for undescribed species of the genus Leptestheria from Colombia, as well as for some populations of Australian Limnadia species, and for all species of Eulimnadia, where, if present, males are very rare (Sassaman, 1995).

The purpose of this study was to analyse the occurrence of clam shrimps in relation to physical and chemical parameters of temporary ponds in Lonjsko Polje, in order to determine the association of groups of species with a set of basic environmental variables. Furthermore, some aspects of the population dynamics and of the associated fauna assemblage, that were both investigated during this study, contribute to the overall knowledge on the Spinicaudata. Considering the great variety in modes of reproduction within the spinicaudatan group, this research has also been conducted to determine the dominant mode of reproduction in the spinicaudatans that inhabit the area of 'Lonjsko Polje' (part of the Pannonian region). In addition, the growth of Cyzicus tetracerus (Krynicki, 1830) has been described for the first time. 


\section{MATERIAL AND METHODS}

\section{Sampling and laboratory analysis}

Five temporary ponds (marked as A, B, C, D, and E) have been observed from May to December 2004, but specimens were collected from May to October 2004 between $1 \mathrm{pm}$ and $6 \mathrm{pm}$, because the ponds were frozen in December. From May to July, they were sampled at 10 days-intervals, on 2-6 occasions depending on the longevity of the ponds, whereas in October, specimens were collected in ponds B and $\mathrm{C}$ on one occasion, after the ponds had been refilled by rainfall. Semiquantitive samples (Schwoerbel, 1966) were collected with a $200 \mu \mathrm{m}$ mesh D-frame pondnet $(20 \mathrm{~cm}$ in diameter), which was dragged from the centre of the pond to the bank approximately $5 \mathrm{~cm}$ above the bottom. On every occasion, 2-4 samples were collected, depending on pond size and shape ( 2 samples were taken in the smaller and narrower ponds, A, B, and C, while 4 samples were taken in the larger, rounded ponds $\mathrm{D}$ and $\mathrm{E}$ ). The volume of filtrated water was calculated as the product of half of the circular surface of the net and the length of the sampling line. All samples were preserved in $96 \%$ ethanol.

At every sampling, the physical and chemical parameters of the pond were measured, including air and water temperature $\left({ }^{\circ} \mathrm{C}\right)$, DO-dissolved oxygen $(\mathrm{mg}$ $\left.1^{-1}\right)$, alkalinity $\left(\mathrm{mg} \mathrm{l}^{-1} \mathrm{CaCO}_{3}\right), \mathrm{pH}$, and conductivity $\left(\mu \mathrm{S} \mathrm{cm}{ }^{-1}\right)$, while data on monthly rainfall were provided by the National Meteorological Department of Croatia. Water chemistry data were obtained with the following equipment: temperature and dissolved oxygen: WTW Oxi 330/SET; pH: WTW pH-meter 330; conductivity: WTW conductivity meter LF 330; alkalinity and water hardness (German standards): according to APHA (1985).

Species identifications were based on Botnariuc \& Orghidan (1953), Straškraba (1966), Cottarelli \& Mura (1983), Marinček \& Petrov (1985, 1992a, b, 1995-98), and Defaye et al. (1998). The higher taxonomic level of the associated fauna was determined according to Kerovec (1986).

The population density of the species was calculated as inds $\mathrm{m}^{-3}$, the relative abundance of the associated fauna was expressed on a scale from 1 to 5 , ranging from low (1) to high (5) abundance. For each date and at each sampling site, the presence of males and females was recorded, and sex ratio (males : females) was calculated. The fraction of male Spinicaudata was calculated as the mean male percentage in the population over all sampling occasions at each site.

Collected specimens have been deposited at the Department of Zoology (GOTT collection) of the University of Zagreb.

During our study, the length (L) and width (W) of the valves were measured and the length to width valve ratio (L/W) was calculated. They were measured with a compound microscope (PRO-LUX XTL3400D) with an eye-piece micrometer 
at $7 \times$ magnification to $0.01 \mathrm{~mm}$ accuracy. Sex identification was carried out according to Cottarelli \& Mura (1983). Mean value $(\bar{x})$ of valve size, standard error $( \pm \mathrm{SE})$, and standard deviation $( \pm \mathrm{SD})$ were calculated for each sex and sampling date. Independent Chi-square $\left(\chi^{2}\right)$ test was used to compare monthly changes in sex ratios at all study sites. Statistically significant differences with respect to a hypothetical $1: 1$ ratio are referred to when the probability of error for rejecting the null hypothesis was $p<0.01$. Statistical analyses (Zar, 1996) were made using Statistica version 6.0 for Windows (StatSoft Inc., 2002; Zar, 1996).

\section{Sites studied}

All five sites studied are situated in the central part of Lonjsko Polje (fig. 1).

Three out of five ponds (A, D, and E) dried out in late May or early to middle June, remained desiccated the rest of the year, and did not refill in autumn despite abundant rainfall. Two ponds (B and C), which appeared after the withdrawal of the floods in late May, remained during May and June, but dried out in late July and

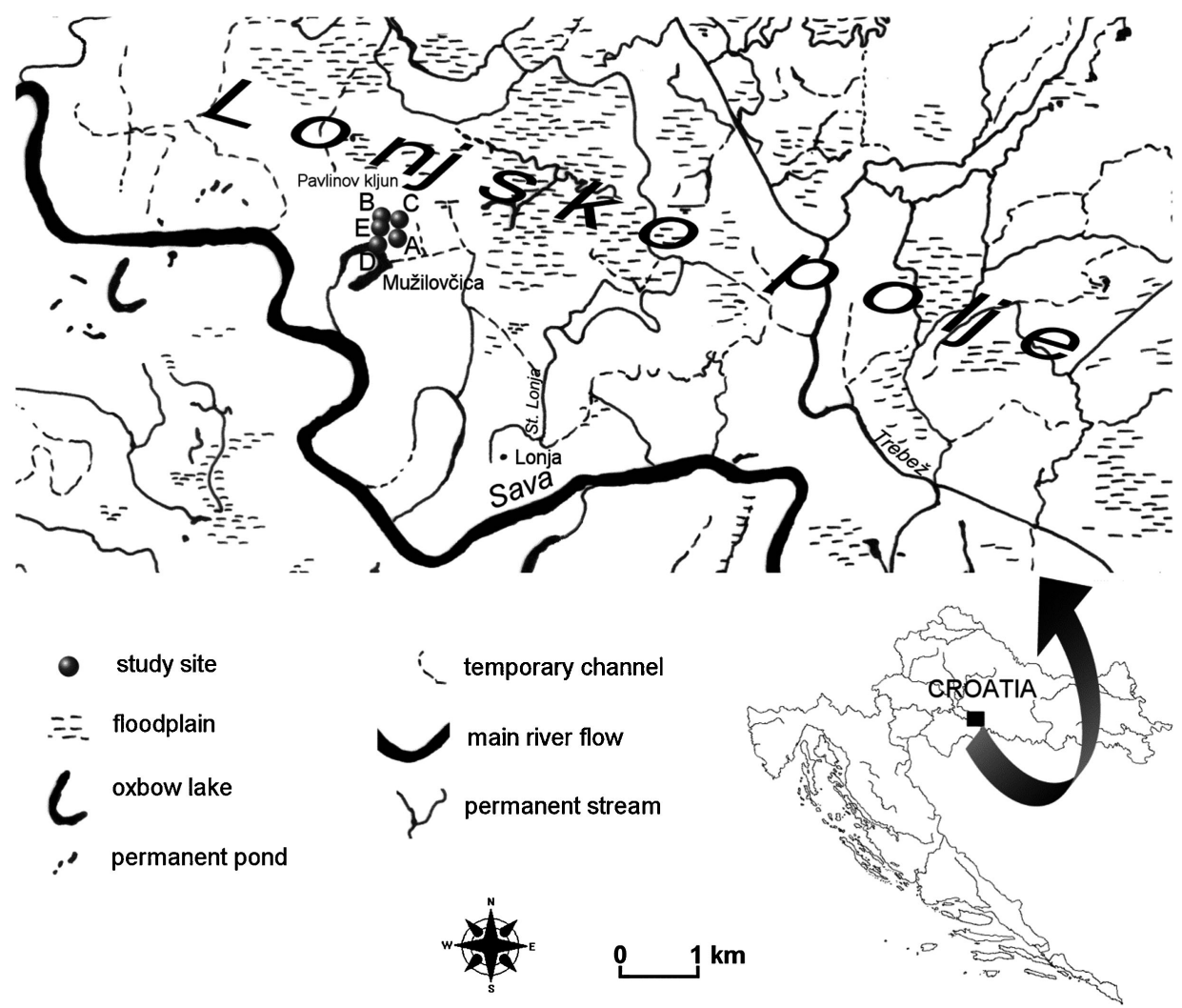

Fig. 1. Sites (ponds) studied, A-E, in the floodplain area of Lonjsko Polje, Croatia. 


\section{TABLE I}

Site locations with key habitat notes. $\left(^{*}\right)$ indicates partially shaded ponds; $\left(^{* *}\right)$ indicates almost completely shaded ponds; $\downarrow$, pond fed by rainfall; $\uparrow$, pond fed by groundwater

\begin{tabular}{|c|c|c|c|c|c|}
\hline Site & Latitude & Longitude & Sediment type & Pond duration & Refill \\
\hline $\mathrm{A} \downarrow^{*}$ & $45^{\circ} 23^{\prime} 33.7^{\prime \prime} \mathrm{N}$ & $16^{\circ} 41^{\prime} 0.6^{\prime \prime} \mathrm{E}$ & clay, mud & early to middle May & - \\
\hline $\mathrm{B} \downarrow^{*}$ & $45^{\circ} 23^{\prime} 58.9^{\prime \prime} \mathrm{N}$ & $16^{\circ} 41^{\prime} 31.3^{\prime \prime} \mathrm{E}$ & clay & late May - late August & late October \\
\hline $\mathrm{C} \downarrow$ & $45^{\circ} 23^{\prime} 58.9^{\prime \prime} \mathrm{N}$ & $16^{\circ} 41^{\prime} 31.3^{\prime \prime} \mathrm{E}$ & clay & $\begin{array}{l}\text { late May - middle June } \\
\text { early July - late August } \\
\text { late October }\end{array}$ & $\begin{array}{l}\text { early July } \\
\text { late October }\end{array}$ \\
\hline $\mathrm{D} \downarrow \uparrow * *$ & $45^{\circ} 21^{\prime} 25.6^{\prime \prime} \mathrm{N}$ & $16^{\circ} 46^{\prime} 13.6^{\prime \prime} \mathrm{E}$ & soil, leaf litter & early to late May & - \\
\hline $\mathrm{E} \downarrow \uparrow * *$ & $45^{\circ} 23^{\prime} 33.7^{\prime \prime} \mathrm{N}$ & $16^{\circ} 41^{\prime} 09.5^{\prime \prime} \mathrm{E}$ & soil, leaf litter & early May - early June & - \\
\hline
\end{tabular}

were refilled in October after heavy rains. In addition, pond $\mathrm{C}$ also desiccated by mid-June and refilled early July (table I). All ponds were empty during November and frozen in December of 2004.

Changes in the pond sizes during the surveyed period are shown in fig. 2. In this period, the largest rainfall was reported in April and September 2004 (145 mm and $123 \mathrm{~mm}$, respectively; National Meteorological Department of Croatia), which is common for the southern Middle-European Pannonian region (Schneider-Jacoby \& Ern, 1993).

The temperature regime registered was: air $13.0-25.3^{\circ} \mathrm{C}(\bar{x} \pm \mathrm{SD}=17.8 \pm 3.9)$, water $11.2-32.9^{\circ} \mathrm{C}(\bar{x} \pm \mathrm{SD}=18.24 \pm 6.15)$. DO levels ranged from 1.95 to $10.60 \mathrm{mg} \mathrm{l}^{-1}(\bar{x} \pm \mathrm{SD}=4.57 \pm 2.39) ; \mathrm{pH}$ values of the water were neutral (6.9) to alkaline (9.2) ( $\bar{x} \pm \mathrm{SD}=7.8 \pm 0.58)$. Conductivity varied considerably, depending on the origin of the pond water, reaching a maximum of $915 \mu \mathrm{S} \mathrm{cm}^{-1}$ in pond $\mathrm{E}\left(\bar{x} \pm \mathrm{SD}=491.05 \pm 232.23 \mu \mathrm{S} \mathrm{cm}^{-1}\right)$. Alkalinity ranged from 75 to $445 \mathrm{mg} \mathrm{l}^{-1} \mathrm{CaCO}_{3}(\bar{x} \pm \mathrm{SD}=252.26 \pm 103.88)$, but the majority of the ponds examined during the entire research period (May to October 2004) contained water of medium hardness. Certain differences in physico-chemical characteristics between the ponds surveyed are shown in table II.

\section{RESULTS}

Three species of spinicaudatans were collected in the research area: Cyzicus tetracerus (Krynicki, 1830), Eoleptestheria ticinensis (Balsamo-Crivelli, 1859), and Leptestheria dahalacensis (Rüppell, 1837). Cyzicus tetracerus was found in four (A, B, C, and D) out of five ponds surveyed, Eoleptestheria ticinensis was found in one pond (A), as was Leptestheria dahalacensis (pond C). In one pond (E), no spinicaudatans were found. 

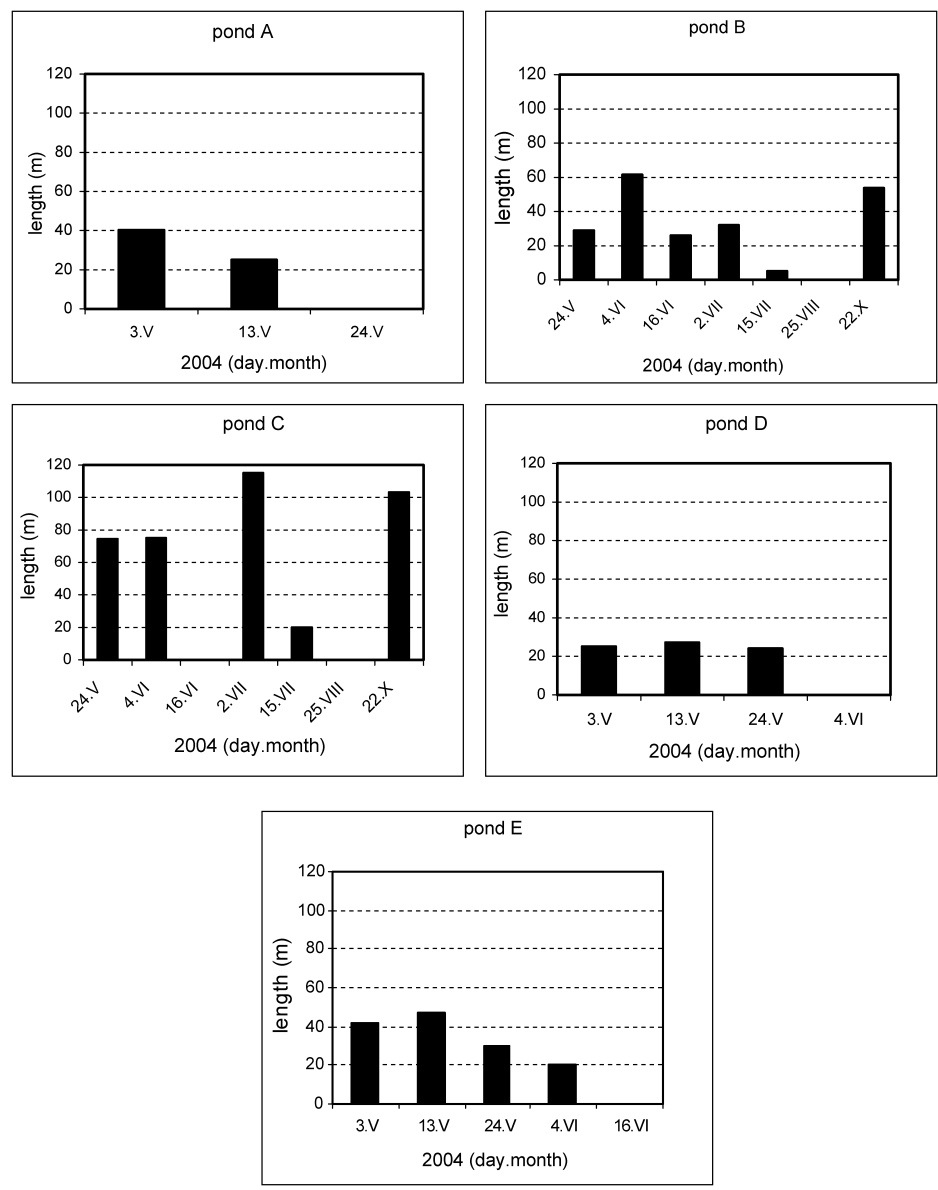

Fig. 2. Changes in the length of the ponds surveyed (ponds A, B, C, D, and E) during the research period from May to October 2004.

A total of 315 organisms was collected in 52 samples (291 C. tetracerus, 19 E. ticinensis, and $5 \mathrm{~L}$. dahalacensis). Leptestheria dahalacensis is left out of the analyses, because of the small number obtained.

\section{CyZICIDAE Stebbing, 1910}

\section{Cyzicus tetracerus (Krynicki, 1830)}

Males were somewhat more abundant than females in all ponds during the whole research period. However, males significantly outnumbered females at the beginning of the season in pond A (early May), but the opposite occurred in midMay. In pond B, males were less abundant than females in comparison to pond A, and sex ratio changed during the research period. Males significantly outnumbered 


\section{TABLE II}

The range of physico-chemical characteristics of five ponds surveyed during the research period from May to October 2004 in the alluvial wetland Lonjsko Polje

\begin{tabular}{lcccccc}
\hline Site & $\begin{array}{c}\text { Air temp. } \\
\left({ }^{\circ} \mathrm{C}\right)\end{array}$ & $\begin{array}{c}\text { Water temp. } \\
\left({ }^{\circ} \mathrm{C}\right)\end{array}$ & $\begin{array}{c}\mathrm{DO} \\
\left(\mathrm{mg} \mathrm{l}^{-1}\right)\end{array}$ & $\mathrm{pH}$ & $\begin{array}{c}\text { Conductivity } \\
\left(\mu \mathrm{S} \mathrm{cm}^{-1}\right)\end{array}$ & $\begin{array}{c}\mathrm{CaCO}_{3} \\
\left(\mathrm{mg} \mathrm{l}^{-1}\right)\end{array}$ \\
\hline pond A & $22.8-23.5$ & $23.0-25.8$ & $1.9-6.2$ & $7.7-7.9$ & $452-565$ & $270-335$ \\
pond B & $15.0-22.2$ & $12.2-32.9$ & $3.6-7.8$ & $6.9-8.5$ & $292-491$ & $100-240$ \\
pond C & $15.0-25.3$ & $12.3-29.0$ & $3.2-10.6$ & $6.9-9.2$ & $225-480$ & $75-330$ \\
pond D & $14.0-15.7$ & $12.1-17.2$ & $2.0-5.5$ & $7.5-8.1$ & $426-474$ & $210-310$ \\
pond E & $13.0-15.0$ & $11.2-15.2$ & $2.0-4.2$ & $7.8-8.1$ & $837-915$ & $365-445$ \\
\hline
\end{tabular}

\section{TABLE III}

Fraction of males, distribution of sexes, and sex ratio (males : females) in three populations of Cyzicus tetracerus (Krynicki, 1830) from May to October 2004 in Lonjsko Polje. The Chi-square $\left(\chi^{2}\right)$ value tests the hypothesis that males and females are equally frequent $(1: 1)$. Statistically significant values $(p<0.01)$ are indicated (ns, nonsignificant)

\begin{tabular}{llcccc}
\hline Site & Sample & Proportion male (\%) & Sex ratio & $\chi^{2}$ & $P$ \\
\hline A & May 3 & 60 & 1.54 & 9.31 & $<0.005$ \\
& May 13 & & 0.20 & 8.00 & $<0.005$ \\
B & May 24 & 47 & 14.00 & 11.27 & $<0.001$ \\
& June 3 & & 1.60 & 0.69 & $\mathrm{~ns}$ \\
& June 16 & & 0.50 & 0.67 & $\mathrm{~ns}$ \\
& October 22 & & 0.00 & 3.00 & $\mathrm{~ns}$ \\
& May 24 & \multirow{2}{*}{51} & 1.20 & 0.09 & $\mathrm{~ns}$ \\
$\mathrm{C}$ & June 3 & & 3.00 & 1.00 & $\mathrm{~ns}$ \\
& October 22 & & 0.30 & 3.77 & $\mathrm{~ns}$ \\
\hline
\end{tabular}

females during late May, and then decreased before the pond dried out. Sex ratio fluctuated in pond $\mathrm{C}$, where the sexes occurred in equal frequency during late May, but at the beginning of June the number of males increased, and in autumn females outnumbered males (table III).

The maximum life span of a reproducing generation in pond A was three weeks, which coincided with the existence of pond A, that appeared after heavy rains in early May and desiccated in late May due to a rise in air temperature and evaporation. Individuals reached sexual maturity in mid-May, when almost all sampled females had laid eggs. At the same time, a huge number of individuals were found dead. The species was found in pond B from late May to mid-June. The females reached sexual maturity in late May, soon after the formation of the pond, when all sampled females had laid eggs. For the spring generation, the life span in pond B was completed in one month. Although the pond existed in July, $C$. tetracerus was not present any longer. After heavy rains and refilling in October, a 


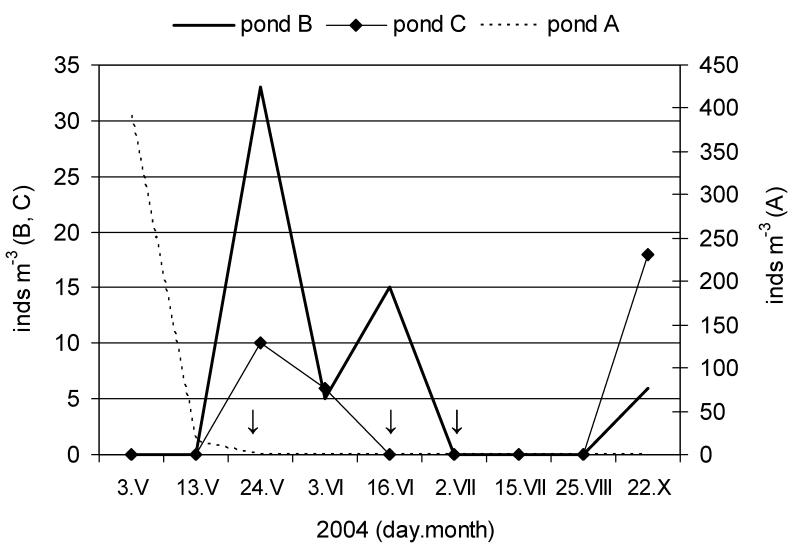

Fig. 3. Changes in population density of Cyzicus tetracerus (Krynicki, 1830) during May, June, and October 2004 in pond A, B, and C. Arrows indicate progressive drying of ponds.

second, autumn generation of $C$. tetracerus developed, but only immature females were found. C. tetracerus was present in pond C from late May to early June, until the first desiccation of the pond, and it was not found in July despite refilling of the pond. The second refilling took place in late October, when a second generation developed. The lifespan of the spring generation was three weeks. C. tetracerus was found in pond D in late May, when only one male was sampled. In late June, the pond had almost completely desiccated, making sampling impossible. However, in the pond residue five sexually mature females were found, three of which had laid eggs.

The population density of $C$. tetracerus in pond A significantly decreased during May, from 392 inds $\mathrm{m}^{-3}$ in the beginning of the month, to 15 inds $\mathrm{m}^{-3}$ in midMay. Because no quantitative samples of $C$. tetracerus were collected during the existence of pond D from early May to early June, the density of this small population could not be deduced. Changes in population density at sites B and C during the research period are depicted in fig. 3 .

Valve growth in both sexes varied among the different populations. The populations in separate pools had different a valve length and width, even on the same sampling date (females in October). Males in pond $\mathrm{C}$ were larger than females during the whole study period, which differs from the observations in ponds $\mathrm{A}$ and B, with the exception of the sample from late May (valve width in males was smaller than that in females). In October, individuals were smaller, which indicates the development of the second generation. The length to width ratio of the valves stayed the same during the whole research period, and at all sites, indicating a proportional growth rate in valve length and width in both males and females (table IV). 


\section{TABLE IV}

Length and width of male (ML, MW) and female (FL, FW) valves and length to width ratio in males $(\mathrm{M} \mathrm{l} / \mathrm{w})$ and females (F 1/w) (mean $\pm \mathrm{SD}$ ) in Cyzicus tetracerus (Krynicki, 1830) in pond A during May 2004 and in ponds B and C from May to October 2004 (* only one individual is present in the sample)

\begin{tabular}{llcccccccc}
\hline Date & $\mathrm{N}$ & $\mathrm{ML}(\mathrm{mm})$ & $\mathrm{MW}(\mathrm{mm})$ & $\mathrm{N}$ & $\mathrm{FL}(\mathrm{mm})$ & $\mathrm{FW}(\mathrm{mm})$ & $\mathrm{M} 1 / \mathrm{w}$ & $\mathrm{F} \mathrm{l} / \mathrm{w}$ \\
\hline A $3 . \mathrm{V}$ & 126 & $6.21 \pm 0.68$ & $4.12 \pm 0.43$ & 82 & $6.43 \pm 0.74$ & $4.27 \pm 0.51$ & $1.51 \pm 0.08$ & $1.51 \pm 0.05$ \\
& 13.V & 3 & $6.66 \pm 0.35$ & $4.43 \pm 0.24$ & 15 & $8.05 \pm 0.35$ & $5.30 \pm 0.18$ & $1.50 \pm 0.05$ & $1.52 \pm 0.04$ \\
B 24.V & 14 & $11.52 \pm 0.45$ & $7.49 \pm 0.23$ & 1 & $12.57^{*}$ & $8.43^{*}$ & $1.54 \pm 0.03$ & $1.49^{*}$ \\
& 3.VI & 8 & $11.87 \pm 1.54$ & $7.77 \pm 0.94$ & 5 & $12.28 \pm 0.97$ & $8.15 \pm 0.54$ & $1.53 \pm 0.10$ & $1.51 \pm 0.05$ \\
& 16.VI & 2 & $11.92 \pm 1.51$ & $7.78 \pm 0.50$ & 4 & $12.75 \pm 0.54$ & $8.46 \pm 0.66$ & $1.53 \pm 0.10$ & $1.51 \pm 0.10$ \\
& 22.X & - & - & - & 3 & $7.29 \pm 0.15$ & $4.76 \pm 0.21$ & - & $1.53 \pm 0.04$ \\
C 24.V & 6 & $11.95 \pm 0.57$ & $7.78 \pm 0.43$ & 5 & $11.91 \pm 1.06$ & $8.46 \pm 0.12$ & $1.54 \pm 0.03$ & $1.41 \pm 0.12$ \\
3.VI & 3 & $11.62 \pm 1.37$ & $7.76 \pm 0.79$ & 1 & $10.71^{*}$ & $7.14^{*}$ & $1.50 \pm 0.05$ & $1.50^{*}$ \\
22.X & 3 & $8.48 \pm 0.16$ & $5.67 \pm 0.08$ & 10 & $8.12 \pm 1.20$ & $5.21 \pm 0.75$ & $1.50 \pm 0.01$ & $1.56 \pm 0.04$ \\
\hline
\end{tabular}

The data on $C$. tetracerus populations in ponds $\mathrm{A}, \mathrm{B}$, and $\mathrm{C}$ was summarized in order to obtain the differences in valve dimensions between sexually mature and immature females. Mature females that were found with full egg sacs were considerably larger than immature ones (females without eggs) (fig. 4). The average valve length of sexually mature females was $9.17 \pm 1.78 \mathrm{~mm}(\bar{x} \pm \mathrm{SD})$, while valve width was $6.06 \pm 1.23 \mathrm{~mm}$. The valve dimensions of the sexually immature females were smaller than those in mature ones (length $\bar{x} \pm \mathrm{SD}=$ $7.09 \pm 1.91 \mathrm{~mm}$; width $\bar{x} \pm \mathrm{SD}=4.75 \pm 1.36 \mathrm{~mm}$ ).

\section{LEPTESTHERIIDAE Daday, 1923}

\section{Eoleptestheria ticinensis (Balsamo-Crivelli, 1859)}

Eoleptesteria ticinensis was found only in pond A in mid-May 2004, together with Cyzicus tetracerus. In early May, when the pond appeared, E. ticinensis was not found. The life span was therefore estimated to last ten days, from mid-May to the desiccation of the pond by late May. In mid-May, the population density was 32 inds $\mathrm{m}^{-3}$ at the time when that of $C$. tetracerus was only 15 inds $\mathrm{m}^{-3}$. Males were less abundant than females, making up $31 \%$ of the E. ticinensis population. The male valves were larger than the females'. The average male valve length was $6.9 \pm 0.54 \mathrm{~mm}(\bar{x} \pm \mathrm{SD})$, width $4.45 \pm 0.43 \mathrm{~mm}$, and female valve length was $6.65 \pm 0.95 \mathrm{~mm}$, width $4.37 \pm 0.62 \mathrm{~mm}$. The length to width ratio of the valves was slightly larger in males, with an average value of $1.56 \pm 0.07$, while in females it was $1.53 \pm 0.12$ (fig. 5). In mid-May, only $9 \%$ of the females had laid eggs, while only $4 \%$ of the sampled individuals were found dead. This indicates that the population had not yet reached sexual maturity by mid-May. Because of the 


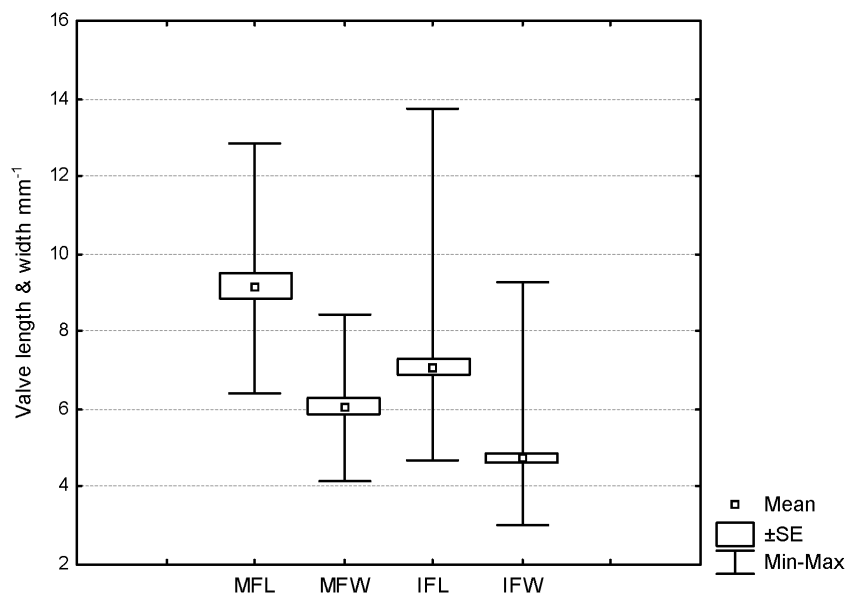

Fig. 4. Comparison of descriptive statistical parameters (mean, SE, and min-max) for valve length (L) and width (W) of Cyzicus tetracerus (Krynicki, 1830) in mature (MF) and immature (IF) females during the research period from May to October 2004 (number of mature and immature females:

$$
\left.\mathrm{N}_{\mathrm{MF}}=32, \mathrm{~N}_{\mathrm{IF}}=99\right) \text {. }
$$

extremely short life span, individuals of E. ticinensis were present in pond A only in one sample during the whole research period from May to October 2004.

\section{Leptestheria dahalacensis (Rüppell, 1837)}

Leptesteria dahalacensis inhabited only pond C in mid-July 2004, when no other spinicaudatan species were present in the pond. A population of Cyzicus tetracerus had developed in the same pond, but during May, June, and October. After the first refilling of the pond in July, the population of L. dahalacensis had developed in mid-July, and remained until the second desiccation, at the beginning of August. Therefore, the life cycle must have been completed in around two weeks.

Mean valve length in males was $9.35 \mathrm{~mm}$, and in females $8.95 \mathrm{~mm}$. Male valve width was $5.00 \mathrm{~mm}$, and female valves were $5.43 \mathrm{~mm}$ wide. The length to width ratio was larger in males, with a mean value of 1.87 , while in females that value was 1.65 .

\section{Ecological notes}

In all ponds surveyed, the most abundant faunal elements were copepods, while other crustaceans (Anostraca, Cladocera, Isopoda, Notostraca, and Ostracoda) were less abundant. The insect fauna was represented by three taxa: Coleoptera, Plecoptera, and Diptera. Coleopterans were found in four out of five ponds with an average relative abundance of 1 , when both larval and adult stages were observed. 

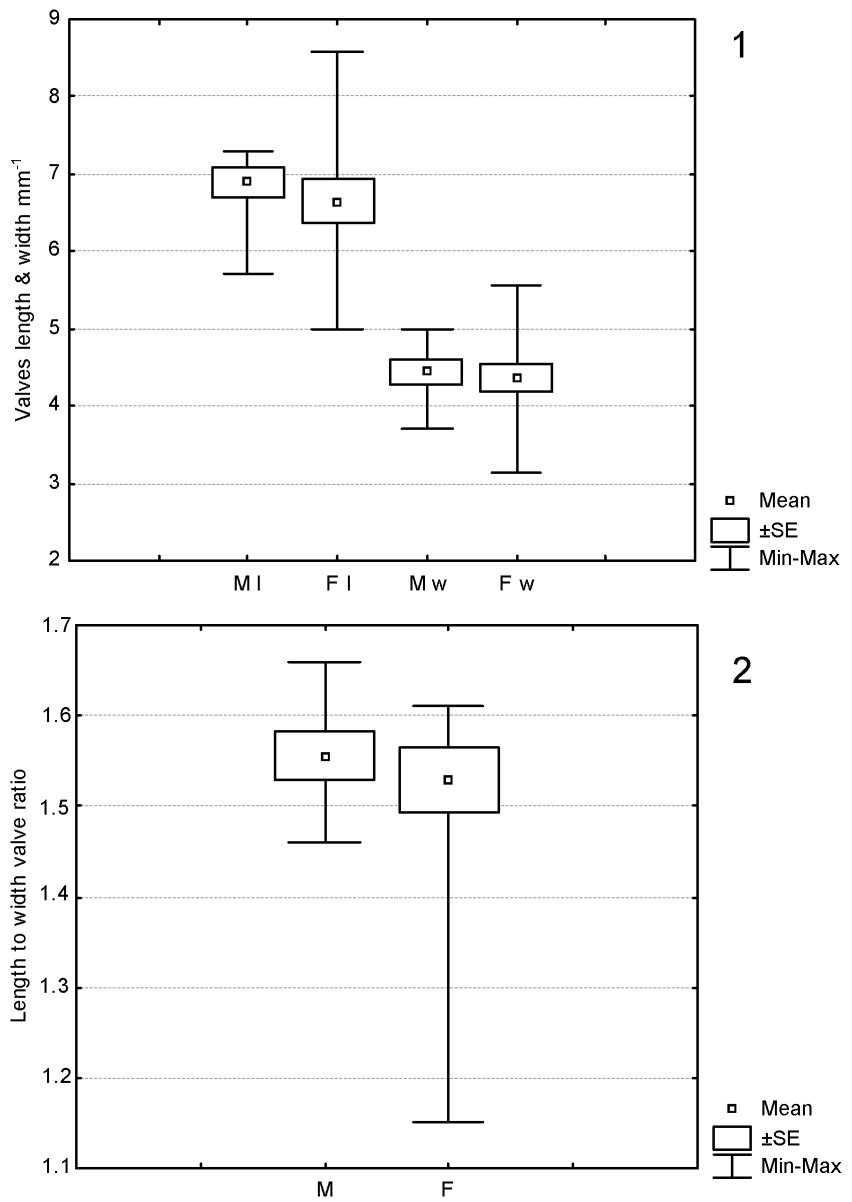

Fig. 5. Comparison of descriptive statistical parameters (mean, SE, and min-max) for length (L) and width $(\mathrm{W})$ of male $(\mathrm{M})$ and female $(\mathrm{F})$ valves (1) and for the length to width ratio of male and female valves (2) in Eoleptestheria ticinensis (Balsamo-Crivelli, 1859) in pond A during mid-May 2004 (number of males and females: $\mathrm{N}_{\mathrm{M}}=7, \mathrm{~N}_{\mathrm{F}}=12$ ).

Plecopteran larvae were found in only two ponds with low abundance (1), while dipteran larvae were very abundant in all ponds with a value of 3 . Gastropods were also quite abundant in all ponds surveyed, with an average relative abundance of 3. Five other taxa (Acarina, Aranea, Diplura, Nematoda, and Oligochaeta) were present with low relative abundances. The associated fauna of large branchiopods included two Notostraca (Triops cancriformis (Bosc, 1801) and Lepidurus apus (L., 1758)), and one anostracan species (Branchipus schaefferi (Fischer, 1834)). Cyzicus tetracerus is frequently syntopic with all other large Branchiopoda, while the notostracan Lepidurus apus monopolizes pond E where soil sediment was covered with fallen leaves (table I), and no other large Branchiopoda co-occurred 


\section{TABLE V}

Percentage composition of the associated fauna recorded from five ponds in the alluvial wetland Lonjsko Polje during the research period in 2004. Abbreviations for large Branchiopoda recorded in each pond: Bs - Branchipus schaefferi (Fischer), Ct - Cyzicus tetracerus (Krynicki), Et - Eoleptestheria ticinensis (Balsamo-Crivelli), Ld - Leptestheria dahalacensis (Rüppell), La Lepidurus apus (L.), Tc - Triops cancriformis (Bosc)

\begin{tabular}{lccccc}
\hline \multicolumn{1}{c}{} & \multicolumn{5}{c}{ Relative abundance (\%) } \\
\cline { 2 - 6 } & $\begin{array}{c}\text { Pond A } \\
\text { May }\end{array}$ & $\begin{array}{c}\text { Pond B } \\
\text { May-October }\end{array}$ & $\begin{array}{c}\text { Pond C } \\
\text { May-October }\end{array}$ & $\begin{array}{c}\text { Pond D } \\
\text { May }\end{array}$ & $\begin{array}{c}\text { Pond E } \\
\text { May-June }\end{array}$ \\
\hline Nematoda & 5 & - & 2 & 3 & 4 \\
Gastropoda & 14 & 18 & 13 & 11 & 15 \\
Oligochaeta & - & - & - & - & 2 \\
Ostracoda & 18 & 12 & 28 & 10 & 9 \\
Copepoda & 22 & 15 & 16 & 23 & 20 \\
Cladocera & 17 & 18 & 13 & 20 & 13 \\
Isopoda & - & 3 & 2 & 10 & 12 \\
Amphipoda & 5 & - & - & - & 4 \\
Plecoptera & - & 6 & 9 & 7 & - \\
Coleoptera & 5 & 4 & 16 & 16 & 7 \\
Diptera & 14 & 24 & Ct, Ld & Ct, La & La \\
Large & & & &
\end{tabular}

with it. Differences in the structure and abundance of the associated fauna between the ponds surveyed are shown in table V.

After taking into consideration all four populations of $C$. tetracerus observed (ponds A, B, C, and D), it was found that the species was euryecious, occurring in wide range of environmental conditions. Specimens of $C$. tetracerus were collected at an air temperature of 14.9 to $24.0^{\circ} \mathrm{C}$ and a water temperature from 12.1 to $33.0^{\circ} \mathrm{C}$. E. ticinensis was found at $22.8^{\circ} \mathrm{C}$ and a water temperature of $23.0^{\circ} \mathrm{C}$, while $L$. dahalacensis occurred at $25.1^{\circ} \mathrm{C}$ and a water temperature of $29.0^{\circ} \mathrm{C}$. As far as the dissolved oxygen concentration was concerned, $C$. tetracerus endured a wide range of concentrations, from 1.9 to $10.5 \mathrm{mg} \mathrm{l}^{-1}$, L. dahalacensis the value of $6.6 \mathrm{mg} \mathrm{l}^{-1}$, while E. ticinensis was found sustaining at the very low dissolved oxygen level of $1.95 \mathrm{mg}^{-1}$. Neutral $\mathrm{pH}$ values from 7.25 to 7.6 suited E. ticinensis and $L$. dahalacensis, while $C$. tetracerus was found to endure moderate to high alkaline values from $\mathrm{pH} 8.25$ to 9.1. Conductivity values for $C$. tetracerus ranged from 255 to $560 \mu \mathrm{S} \mathrm{cm}^{-1}$, while E. ticinensis was found at $560 \mu \mathrm{S} \mathrm{cm}^{-1}$, and L. dahalacensis at $280 \mu \mathrm{S} \mathrm{cm}^{-1}$. In addition, C. tetracerus was found at 8-19 $\mathrm{d}^{\circ} \mathrm{H}$, which signifies very hard water, while $E$. ticinensis and $L$. dahalacensis both occurred at 18-19 $\mathrm{d}^{\circ} \mathrm{H}$ (even higher hardness). 


\section{DISCUSSION}

During the research period, i.e., from May to December 2004, three species of Spinicaudata were found in the Nature Park Lonjsko Polje. All three, Cyzicus tetracerus, Eoleptestheria ticinensis, and Leptestheria dahalacensis are new for the area. In one pond (E) out of five temporary ponds surveyed, no spinicaudatans were found. The distribution pattern suggests that Spinicaudata are absent from pond E because the water conductivity is much higher $\left(837-915 \mu \mathrm{S} \mathrm{cm}^{-1}\right)$, although populations of Cyzicus grubei (Simon, 1886) from SW Portugal were recorded at an even higher conductivity (200-3800 $\mu \mathrm{S} \mathrm{cm}^{-1}$ ) (Machado et al., 1999).

The most widespread and abundant spinicaudatan observed in Lonjsko Polje is $C$. tetracerus, which is similar to the results obtained for the Pannonian part of Serbia (Petrov \& Miličić-Cvetković, 1997). The species was found to endure a wide range of physico-chemical variables of the water (temperature, concentration of dissolved oxygen, alkalinity, conductivity, and water hardness), while E. ticinensis and $L$. dahalacensis occurred rarely, possibly due to their narrower range of physico-chemical tolerance. The population density trend of spinicaudatans in Lonjsko Polje appeared to conform to a pattern observed in the Portuguese and Spanish populations of some spinicaudatans (cf. Machado et al., 1999; Pérez-Bote et al., 2004).

A large branchiopod community, including C. tetracerus, E. ticinensis, Triops cancriformis, and Branchipus schaefferi has not been reported from the Pannonian region before (Petrov \& Petrov, 1999; Eder \& Hödl, 2002), although the cooccurrence of $C$. tetracerus with $E$. ticinensis and $T$. cancriformis is not unusual (Petrov \& Petrov, 1999). C. tetracerus was observed as the only species of large branchiopod in two out of five ponds surveyed, which agrees with results of Petrov \& Petrov (1999). L. dahalacensis was found alone in one temporary pond, although usually this species is found to co-exist with $T$. cancriformis and B. schaefferi (cf. Petrov \& Petrov, 1999). Also, according to Eder et al. (1997), L. dahalacensis was found together with either T. cancriformis or Lepidurus apus in the Austrian part of the Pannonian region, but this was not the case in our research.

C. tetracerus is eurythermous, found to endure a wide range of water temperature $\left(12.1\right.$ to $\left.33.0^{\circ} \mathrm{C}\right)$, E. ticinensis was found only at $25.9^{\circ} \mathrm{C}$, while L. dahalacensis is a thermophilous species, observed only at high temperatures from 30.0 to $32.0^{\circ} \mathrm{C}$. L. dahalacensis had already been reported to occur at 30.0 to $32.0^{\circ} \mathrm{C}$ in the Pannonian region of Yugoslavia (Marinček \& Petrov, 1992b), while data on $E$. ticinensis water temperature preferences have not been published until now.

Regarding the fauna associated with the spinicaudatans, the most abundant taxa were copepods and cladocerans, as expected according to Wetzel (2001). The occurrence of isopods in the temporary ponds surveyed at present is unusual, since 
Bazzanti et al. (2003) reports the presence of isopods only in permanent ponds. Dipteran larvae were dominant in all ponds surveyed, which is concordant with Bazzanti et al. (2003). Many studies suggest that pool duration is one of the most important factors affecting community structure in temporary pools (Holland \& Jenkins, 1998; Bilton et al., 2001; Eitam et al., 2004). In the current study, pond duration was an important predictor of large branchiopod community structure, but physico-chemical parameters, sediment type, level of shading, and origin of water were important, too.

C. tetracerus occurred in Lonjsko Polje during spring, from early May to midJune, as well as in autumn (late October). It had already been reported during May and June in the Pannonian region (Eder et al., 1997), but an autumnal generation has not been recorded until now. There were no considerable differences in the ecological parameters of the habitat during the sampling period. Therefore, if there is a substantial amount of rainfall, an autumnal population is likely to develop. It was also interesting that $C$. tetracerus was absent in two ponds during July, even though the ponds did not desiccate during that period. Water temperature was not a limiting factor, because the values recorded were within the species' preferred range. Even though $L$. dahalacensis occurred during June in one of those ponds, competition can be excluded as a limiting factor, because $C$. tetracerus and L. dahalacensis have been found to coexist (Eder et al., 1997). E. ticinensis was found in Lonjsko Polje in mid-May, while it was reported somewhat later in the Austrian part of the Pannonian region, during June and July (Eder et al., 1997). $L$. dahalacensis was reported in July and was not present during autumn despite the refilling of the pond in October, while in Austria, it was reported during May, June, and in autumn (Eder et al., 1997).

Certain morphological differences have been noted among the four populations of $C$. tetracerus in Lonjsko Polje, mostly due to different ontogenetic stages (fig. 6). C. tetracerus males were smaller than females in length and width, similar to the population in Italy (Cottarelli \& Mura, 1983), while the length to width ratio was 1.5. A change in the length to width ratios during the research period suggests proportional growth of males and females. In addition, research has shown a higher growth rate of the valves of females than in those of the males in one of the four C. tetracerus populations (pond A). Both of these observations were not found in the available literature. The E. ticinensis population in Lonjsko Polje has been compared to the others reported for the Pannonian region of Croatia, near the town of Podravska Slatina, and in Serbia, near the village of Kikinda (Marinček, 1978; Marinček \& Valvajter, 1979) (table VI). Specimens from the Lonjsko Polje were found to be much smaller than individuals already observed in Serbia and Croatia, probably due to ontogenetic differences. The differences detected in valve size of $C$. tetracerus between mature and immature females in Lonjsko Polje are 


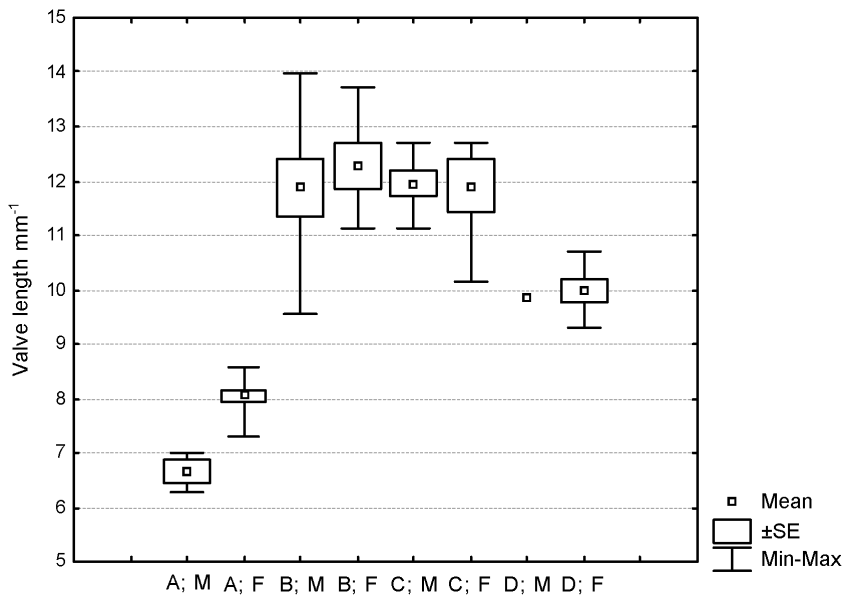

Fig. 6. Comparison of descriptive statistical parameters (mean, SE, and min-max) Cyzicus tetracerus (Krynicki, 1830) male (M) and female (F) valve length (L) in ponds A, B, C, and D in Lonjsko polje during the research period in May and June 2004.

\section{TABLE VI}

Comparison of male and female valve dimensions in Eoleptestheria ticinensis (Balsamo-Crivelli, 1859) in Lonjsko Polje and two other populations in north-central Croatia and Serbia (Marinček,

1978; Marinček \& Valvajter, 1979)

\section{Lonjsko Polje \\ P. Slatina (Croatia)}

5.71-7.29

3.71-4.99

4.99-8.57

3.14-5.57
(Marinček \& Valvajter, 1979)
7.70-8.80

$4.42-5.54$

$6.82-8.12$

4.04-5.10
Kikinda (Serbia)

(Marinček, 1978)
Male valve length (mm)

Male valve width (mm)

Female valve length $(\mathrm{mm})$

Female valve width (mm)
11.06-12.00

$6.78-8.50$

$10.34-12.06$

6.90-8.04

attributable to the existence of various cohorts, while in the Spanish population of C. grubei valve size had a unimodal distribution (Pérez-Bote et al., 2004). This is considered to be a consequence of simultaneous hatching after an inundation. The specimens of $L$. dahalacensis from Lonjsko Polje were found to be considerably larger than the ones in Serbia (cf. Marinček \& Petrov, 1992b), while length to width ratio of the valves was similar (table VII).

The sex ratios of $C$. tetracerus in Lonjsko Polje varied, but were found mostly to be around $1: 1$, which indicates an obligatory sexual mode of reproduction. The total proportion of $C$. tetracerus males in the population was $60 \%$, whereas Sassaman (1995) reported that males comprise $28 \%$.

According to our results, $C$. tetracerus females reached their sexual maturity and laid eggs in mid-May in pond A, only ten days after the formation of the pond and in late May, instantly after pond formation in ponds B and C. In E. ticinensis, 


\section{TABLE VII}

Comparison of male and female valve dimensions and valve length to width ratio in Leptestheria dahalacensis (Rüppell, 1837) in Lonjsko Polje and one in Serbia near Belgrade (Marinček \& Petrov, 1992b)

\section{Lonjsko Polje}

$\begin{array}{cc}8.99-9.71 & 4.40-7.90 \\ 4.86-5.14 & 2.25-4.50 \\ 8.43-10.00 & 4.60-7.70 \\ 4.86-6.29 & 2.85-5.10 \\ 1.85-1.89 & 1.61-1.89 \\ 1.59-1.73 & 1.51-1.87\end{array}$

the majority of females laid eggs sometime between mid-May and late May, when the pond desiccated, about two weeks after the formation of the pond. The females of $L$. dahalacensis reached sexual maturity in mid-July, 13 days after the second refilling of the pond.

The life span of E. ticinensis and L. dahalacensis populations was found to be 10 to 13 days, much shorter than that of $C$. tetracerus, which was 14 to 30 days depending on the water period in the ponds.

\section{CONCLUSIONS}

The spinicaudatans, Cyzicus tetracerus, Eoleptestheria ticinensis and Leptestheria dahalacensis are new records for the area of Lonjsko Polje. Moreover, many ecological data here obtained have not been reported until now, and thus contribute to the overall knowledge on these species: the structure of the large branchiopod community, the water temperature preferences of $C$. tetracerus and E. ticinensis, and the occurrence of the autumnal generation of $C$. tetracerus. Furthermore, this study provides insight into the growth of the valves of these spinicaudatans in both sexes, and gives information about the sex ratio in spinicaudatan populations.

\section{ACKNOWLEDGMENTS}

Special thanks are due to the employees of the Nature Park Lonjsko Polje, and to the National Meteorological Department in Croatia. We send our appreciation to Martina Temunović for sharing both the fun of field trips and the work of sorting and counting specimens. Also, Drs B. Petrov and D. Cvetković-Miličić are acknowledged for their help in providing valuable literature data and assistance in the identification of Cyzicus tetracerus. Finally, the editor and two anonymous referees are acknowledged for their help in improving the manuscript. 


\section{REFERENCES}

APHA, 1985. Standard methods for the examination of water and wastewater: 1-1156. (American Public Health Association, New York).

Bazzanti, M., V. Della Bella \& M. Seminara, 2003. Factors affecting macroinvertebrate communities in astatic ponds in central Italy. Journ. freshw. Ecol., 18 (4): 537-548.

Bilton, D. T., A. Foggo \& S. D. Rundle, 2001. Size, permanence and the proportion of predators in ponds. Arch. Hydrobiol., 151: 451-458.

Botnariuc, N. \& T. Orghidan, 1953. Phyllopoda Crustacea. Fauna Republicii Populare Romane, 4 (2): 1-98. (Academia Republicii Populare Romane, Bucharest).

Cottarelli, V. \& G. Mura, 1983. Anostraci, Notostraci, Concostraci: Guide per il Riconoscimento delle Specie Animali delle Acque Interne Italiane, 18: 1-71. (Consiglio Nazionale delle Ricerche, Verona).

DADAY DE DÉES, E., 1923. Monographie systématique des Phyllopodes Conchostracés, II. Anns. Sci. nat. Zool., Paris, 10 (6): 255-390.

Defaye, D., N. RABET \& A. ThiÉRY, 1998. Atlas et bibliographie des Crustacés Branchiopodes (Anostraca, Notostraca, Spinicaudata) de France métropolitaine: 1-62. (Muséum National d'Histoire Naturelle, Paris).

EdER, E. \& W. HÖDL, 2002. Large freshwater branchiopods in Austria: diversity, threats and conservational status. In: E. ESCOBAR-BRIOnES \& F. Alvarez (eds.), Modern approaches to the study of Crustacea: 281-289. (Kluwer Academic Publishers / Plenum Publishers, New York).

EdER, E., W. HödL \& R. GotTwald, 1997. Distribution and phenology of large branchiopods in Austria. Hydrobiologia, 359: 13-22.

Eitam, A., L. Blaustein, K. Van Damme, H. J. Dumont \& K. Martens, 2004. Crustacean species richness in temporary pools: relationships with habitat traits. Hydrobiologia, 525: 125130.

Holland, T. A. \& D. G. Jenkins, 1998. Comparison of processes regulating zooplankton assemblages in new freshwater pool. Hydrobiologia, 388: 207-214.

Kerovec, M., 1986. Priručnik za upoznavanje beskralješnjaka naših potoka i rijeka: 1-127. (Grafički zavod Hrvatske, Zagreb).

Machado, M., M. CRisto \& L. C. DA FonseCA, 1999. Non-cladoceran branchiopod crustaceans from southwest Portugal. I. Occurrence notes. Crustaceana, 72 (6): 591-602.

Marcus, V. \& S. C. WeEKS, 1997. The effects of pond duration on the life history traits of an ephemeral pond crustacean, Eulimnadia texana. Hydrobiologia, 359: 213-221.

MARINČEK, M., 1978. Eoleptestheria spinosa, a new species of Conchostraca (Phyllopoda) discovered in Yugoslavia. Glasn. Prirod. Muz., Beograd, (B) 33: 104-118.

MARINČEK, M. \& B. Petrov, 1985. Taxonomical study of the genus Leptesteria (Conchostraca, Crustacea) I. Glasn. Prirod. Muz., Beograd, (B) 40: 97-111.

- — \& — - 1991. A review of the Conchostraca (Crustacea) of Yugoslavia. Hydrobiologia, 212: 273-282.

— - \& — - 1992a. Contribution to the knowledge of Notostraca (Branchiopoda, Crustacea) in Yugoslavia. Glasn. Prirod. Muz., Beograd, (B) 47: 123-129.

— — \& — 1992b. On a new speces of the genus Leptestheria G. O. Sars 1896 (Conchostraca, Crustacea). Glasn. Prirod. Muz., Beograd, (B) 47: 107-121.

— — \& — - 1995-98. Taxonomical study of the genus Leptestheria (Conchostraca, Crustacea) II. Glasn. Prirod. Muz., Beograd, (B) 49-50: 129-143.

MATINČEK, M. \& B. VALVAJTER, 1979. Eoleptestheria spinosa tenuis, a new subspecies of Conchostraca (Phyllopoda) found in Yugoslavia. Glasn. Prirod. Muz., Beograd, (B) 34: 155167. 
Nicolet, P., J. Biggs, G. Fox, M. J. Hodson, C. Reynolds, M. Whitfield \& P. Williams, 2004. The wetland and macroinvertebrate assemblages of temporary ponds in England and Wales. Biol. Conserv., 120: 261-278.

Pérez-Bote, J. L., A. Muñoz, A. J. Romero, R. Roso, E. Méndez, A. Belén Martín \& M. T. López, 2004. Nuevos datos sobre la biologa de Cyzicus grubei (Simon, 1886) en la Península Ibérica (Crustacea, Spinicaudata). Boln Asoc. Español Ent., 28 (3-4): 81-87.

Petrov, B. \& D. Miličić-CVetković, 1997. The status of Anostaca, Notostraca and Conchostraca (Crustacea: Branchiopoda) in Yugoslavia. Hydrobiologia, 359: 29-35.

Petrov, B. \& I. Petrov, 1999. Multispecies coexistence of branchiopods (Anostraca, Notostraca and Conchostarca) in Yugoslavia. Contributions to the Zoogeography and Ecology of the Eastern Mediterranean Region, 1: 387-392.

RAMSAR, 2005. The list of wetlands of international importance: 1-36. (The Secretariat of the Convention on Wetlands, Gland).

Sassaman, C., 1995. Sex determination and evolution of unisexuality in the Conchostraca. Hydrobiologia, 298: 46-65.

SCHNEIDER-JACOBY, M. \& H. ERN, 1993. Park prirode Lonjsko polje. Raznolikost uvjetovana poplavljivanjem: 1-135. (Hrvatsko ekološko društvo, Zagreb).

Schwoerbel, J., 1966. Methoden der Hydrobiologie: 1-207. (Kosmos-Gesellschaft der Naturfreunde, Franckh'sche Verlagshandlung, Stuttgart).

StATSOFT, InC., 2002. Statistica electronic manual. Version 6. (Tulsa).

STRAŠKRABA, M., 1966. Taxonomical studies on Czechoslovak Conchostraca III. Family Leptestheriidae, with some remarks on the variability and distribution of Conchostraca and a key to the Middle-European species. Hydrobiologia, 27: 571-589.

Wetzel, R. G., 2001. Limnology. Lake and river ecosystem: i-xvi, 1-1006. (Academic Press, San Diego).

ZAR, J. H., 1996. Biostatistical analysis: i-x, 1-662. app. 1-205, ans. 1-11, 1.1-19, i.1-21. (PrenticeHall International, London). 